\title{
USE OF THE ABI TECHNIQUE TO MEASURE THE MECHANICAL PROPERTIES OF ALUMINIUM ALLOYS: EFFECT OF HEAT-TREATMENT CONDITIONS ON THE MECHANICAL PROPERTIES OF ALLOYS
}

\author{
UPORABA ABI TEHNIKE ZA MERJENJE MEHANSKIH \\ LASTNOSTI ALUMINIJEVIH ZLITIN: VPLIV POGOJEV \\ TOPLOTNE OBDELAVE NA MEHANSKE LASTNOSTI ZLITIN
}

\author{
Oleksandr Trudonoshynn, ${ }^{1,2}$, Maxim Puchnin ${ }^{1}$, Olena Prach ${ }^{1,3}$ \\ ${ }^{1}$ Czech Technical University in Prague, Karlovo náměstí 13, 12135, Prague 2, Czech Republic \\ ${ }^{2}$ Friedrich Alexander Universität Erlangen Nürnberg, Martenstraße 5, 91058 Erlangen, Germany \\ ${ }^{3}$ Technische Universität Darmstadt, Karolinenplatz 5, 64289 Darmstadt, Germany \\ trudonoshyn@fhotm.kpi.ua
}

Prejem rokopisa - received: 2014-12-08; sprejem za objavo - accepted for publication: 2015-05-04

doi: $10.17222 /$ mit.2014.295

\begin{abstract}
Effects of chemical composition and heat treatment on the microstructures and mechanical properties were investigated with automated ball-indentation tests, scanning and transmission electron microscopy, and energy-dispersive X-ray analysis. In this work, the automated ball-indentation (ABI) technique was compared with the standard mechanical tests. The ABI method is based on load-controlled multiple indentations into a polished surface by a spherical indenter. The indentation depth is progressively increased to the specified maximum limit with intermediate partial unloading. This technique allows us to measure the yield strength, the stress-strain curve, the strength coefficient and the strain-hardening exponent. For all the test materials and conditions, the ABI-derived results were in very good agreement with those obtained with conventional standard test methods. We analyzed the effect of heat treatment on the alloys with different chemical compositions. Heat treatment leads to changes in the mechanical properties of the alloys, which are the results of several processes.

Keywords: Al-alloys, heat treatment, tensile strength, yield strength, ABI hardness test
\end{abstract}

Vpliv kemijske sestave in toplotne obdelave na mikrostrukturo in mehanske lastnosti je bil preiskovan $\mathrm{z}$ avtomatiziranim preizkusom trdote $\mathrm{z}$ vtiskovanjem kroglice, z vrstično in presevno elektronsko mikroskopijo in energijsko disperzijsko rentgensko spektroskopijo. V tem delu je bila tehnika avtomatskega vtiskovanja kroglice (ABI) primerjana s standardnimi mehanskimi preizkusi. ABI metoda temelji na kontrolirani obtežitvi pri večkratnem vtiskovanju krogličnega telesa v polirano površino. Globina vtiskovanja postopoma narašča do maksimalne določene globine z vmesnimi razbremenitvami. Ta tehnika omogoča merjenje meje tečenja, krivulje raztezek-obremenitev, koeficienta trdnosti in eksponenta napetostnega utrjevanja. Za vse preizkušane materiale in pogoje, so se dobljeni ABI rezultati dobro ujemali z rezultati dobljenimi iz običajnih metod preizkušanja. Preučevan je bil vpliv toplotne obdelave na zlitine z različno kemijsko sestavo. Toplotna obdelava povzroči spremembo mehanskih lastnosti zlitin, kar je posledica večih procesov.

Ključne besede: Al-zlitine, toplotna obdelava, natezna trdnost, meja tečenja, trdota pri ABI preizkusih

\section{INTRODUCTION}

A large number of aluminum alloys have been developed for casting, but most of them are varieties of six basic types (according to the AA Al alloy designation system): $\mathrm{Al}-\mathrm{Cu}(2 \mathrm{XX} . \mathrm{X}), \mathrm{Al}-\mathrm{Cu}-\mathrm{Si}$ (or Mg) (3XX.X), Al-Si (4XX.X), Al-Mg (5XX.X), Al-Zn-Mg (7XX.X) and Al-St $(8 X X . X) .{ }^{1}$ In this context, the alloys of the Al-Mg-Si (6XXX) system have been widely used in producing sheets, extruded parts and thin-wall castings.

It was reported by $H$. Sternau et al. ${ }^{2}$ that an AlMg5Si2Mn alloy (HPDC) shows high mechanical properties such as ductility (up to $18 \%$ ), yield strength (up to $220 \mathrm{MPa}$ ) and tensile strength (up to $350 \mathrm{MPa}$ ), compared with the other casting alloys.

When comparing the AlSi7Mg and AlMg5Si2Mn casting alloys, the most evident difference is in the fact that the highest strength of AlSi7Mg is achieved only after the heat treatment, whereas AlMg5Si2Mn exhibits its highest properties in the as-cast condition.

Heat-treatable Al-Mg-Si alloys are important for the investigation because of the possible hardening process, which leads to specific properties. The hardening effects are shown when the dislocations interact with the precipitates, which act as obstacles to the dislocation motion. ${ }^{1,3}$ It is well known that the ductility of such alloys decreases with the increasing Si content. Brittle coarse Si particles usually make further deformation difficult. ${ }^{3}$

In this regard, it is important to apply not only the optimum chemical composition of the material but also the optimum heat-treatment conditions. The main task of this paper is to investigate the influence of heat treatment on the mechanical properties and structure of Al-Mg-SiMn alloys. 
Table 1: Nominal compositions of the alloys (Al - bal.), in mass fractions ( $w / \%)$

Tabela 1: Nominalna sestava zlitin (Al - ostalo), v masnih deležih (w/\%)

\begin{tabular}{|c|c|c|c|c|c|c|c|c|}
\hline Alloys & $\mathrm{Mg}$ & $\mathrm{Si}$ & $\mathrm{Mn}$ & $\mathrm{Fe}$ & $\mathrm{Ti}$ & $\mathrm{Cu}$ & $\mathrm{Zn}$ & Comment \\
\hline AlMg6Mn (M3) & 6.0 & 0.4 & 0.6 & 0.3 & 0.1 & 0.1 & 0.1 & $\mathrm{Al}-1 \mathrm{Mg} \mathrm{M}_{2} \mathrm{Si}-5 \mathrm{Mg}$ \\
\hline AlMg7SiMn (MS1) & 7.0 & 1.0 & 0.6 & 0.02 & 0.1 & 0.05 & 0.05 & $\mathrm{Al}-3 \mathrm{Mg} 2 \mathrm{Si}-5 \mathrm{Mg}$ \\
\hline AlMg7Si2Mn (MS2) & 7.0 & 2.0 & 0.6 & 0.02 & 0.1 & 0.05 & 0.05 & $\mathrm{Al}-6 \mathrm{Mg}_{2} \mathrm{Si}-3 \mathrm{Mg}$ \\
\hline AlMg5Si2Mn (M59) & 5.0 & 2.0 & 0.6 & 0.02 & 0.1 & 0.05 & 0.05 & $\mathrm{Al}-6 \mathrm{Mg}_{2} \mathrm{Si}-1 \mathrm{Mg}$ \\
\hline AlMg7Si3Mn (MS3) & 7.0 & 3.0 & 0.6 & 0.02 & 0.1 & 0.05 & 0.05 & $\mathrm{Al}-9 \mathrm{Mg} \mathrm{Mg}_{2} \mathrm{Si}-1 \mathrm{Mg}$ \\
\hline AlMg7Si4Mn (MS4) & 7.0 & 4.0 & 0.6 & 0.02 & 0.1 & 0.05 & 0.05 & $\mathrm{Al}-10.5 \mathrm{Mg} 2 \mathrm{Si}-0.5 \mathrm{Si}$ \\
\hline AlMg7Si5Mn (MS5) & 7.0 & 5.0 & 0.6 & 0.02 & 0.1 & 0.05 & 0.05 & $\mathrm{Al}-10.5 \mathrm{Mg} 2 \mathrm{Si}-1.5 \mathrm{Si}$ \\
\hline AlSi7Mg (S1) & 0.3 & 6.9 & 0.02 & 0.2 & - & 0.05 & 0.05 & $\mathrm{Al}-7 \mathrm{Si}$ \\
\hline
\end{tabular}

The ABI test is used to measure material properties when a conventional technique cannot be applied (welded parts, brittle materials, samples with a high porosity and the parts currently used). ${ }^{4,5}$ As shown previously $^{6}$, the results obtained with this method achieve good compatibility with those of the conventional methods.

\section{MATERIALS AND METHODS}

The chemical compositions of the evaluated alloys are shown in Table $1 .^{6}$

Two types of heat treatment were applied. The first type was the solution treatment, carried out in an electric resistance furnace. After the solution treatment, the specimens were quenched at water at room temperature. The second type of heat treatment was T6, combining solution treatment at $570{ }^{\circ} \mathrm{C}(60 \mathrm{~min})$, quenching in water at room temperature and artificial aging at $175^{\circ} \mathrm{C}$ during various periods.

Indentation tests were carried out using a special device (patent CZ 304637 B1), which, due to its design,
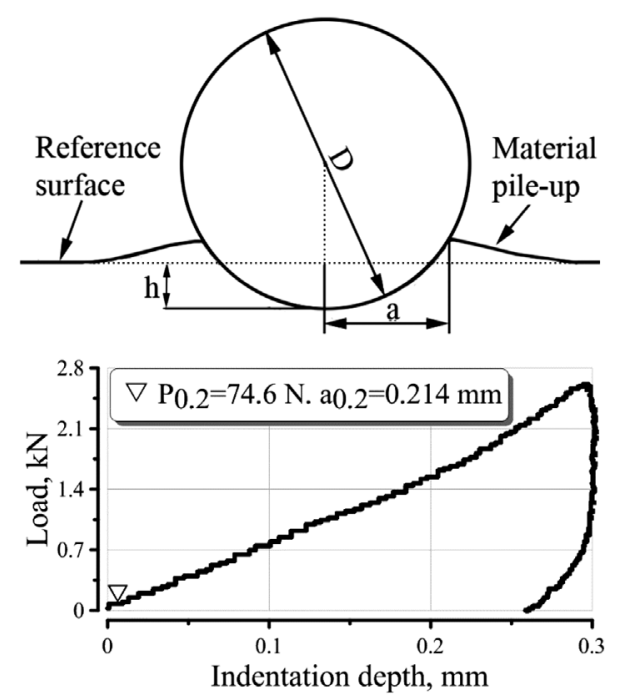

Figure 1: Scheme for determining: a) contact radius, b) indentation curve for the AlMg6Mn alloy

Slika 1: Shematski prikaz za določanje: a) kontaktnega premera, b) krivulja vtiskovanja pri zlitini AlMg6Mn is capable of continuously recording the load and indentation depth of the used indenter. The system includes: a recording device, an analog-to-digital converter, a PC with software and an Instron 5582 tensile-testing machine as the force-producing mechanism. The maximum indentation load was $2.5 \mathrm{kN}$ and the indenter diameter was $5 \mathrm{~mm}$. Plane-parallel samples were used for ABI (automatic ball indentation) testing.

Series of measurements were carried out for all the samples. The obtained $H B$ hardness was compared with the hardness, measured with a standard testing machine. In the case of a good reproducibility of the results (an error of the order of $10 \%$ ) from the obtained curve (Figure 1), values of the yield strength and tensile strength were calculated.

The hardness was calculated with Equation (1):

$$
H B=\frac{P}{\pi D h}
$$

where $H B$ is the Brinell hardness, $P$ is the load $(\mathrm{kN}), D$ is the diameter of the indenter ( $\mathrm{mm}), h$ is the indentation depth (mm) (Figure 1).

For the determination of the tensile strength $\left(R_{\mathrm{m}}\right)$, we used Equation (2): ${ }^{7}$

$$
R_{\mathrm{m}}=c \cdot H B
$$

where $c$ is the coefficient of uncertainty. For the presented series of alloys, we used the following value of this coefficient $-2.8 .^{6}$

For the determination of the yield strength $\left(R_{\mathrm{p} 0.2}\right)$, the methodology proposed in ${ }^{7}$, together with Equation (3), was used. The Meyer hardness was calculated with Equation (4):

$$
\begin{gathered}
R_{\mathrm{p} 0.2}=c \cdot H M \\
H M=\frac{P}{\pi a^{2}}
\end{gathered}
$$

where $c$ is the coefficient of uncertainty (2.8), $H M$ is the Meyer hardness and $a$ is the contact radius.

Using the values of the indentation depth $(h)$, according to Equations (5) and (6), strain values $(\psi)$ and the contact radius $(a)$ were determined. The value of deformation for the yield stress was $0.2 \%$, by analogy with the tensile tests. 


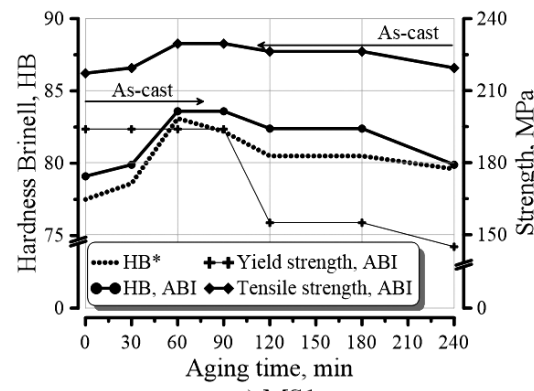

a) MS1

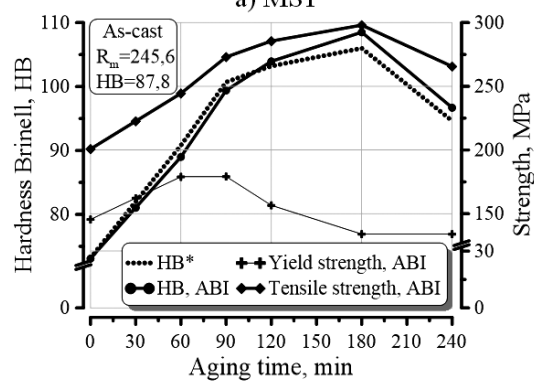

d) MS3

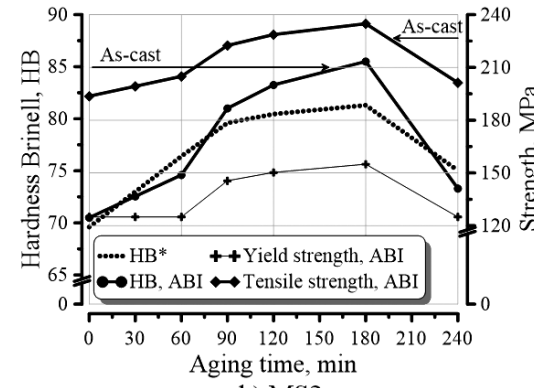

b) $\mathrm{MS} 2$

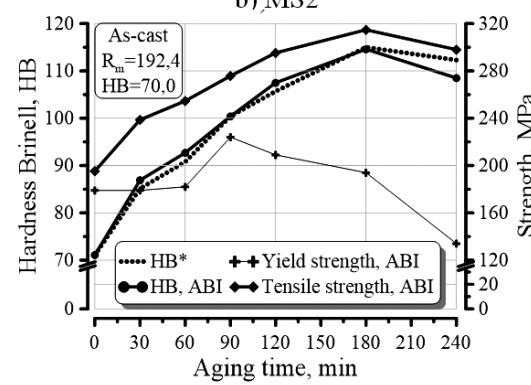

e) MS4

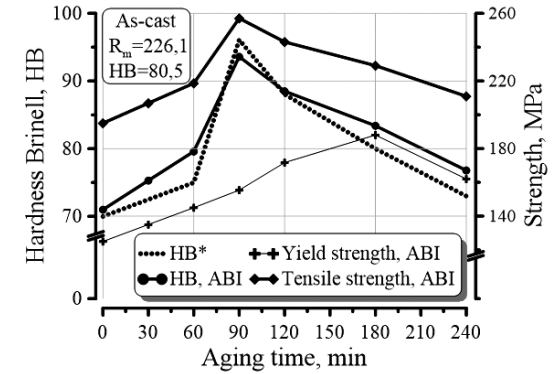

c) M59

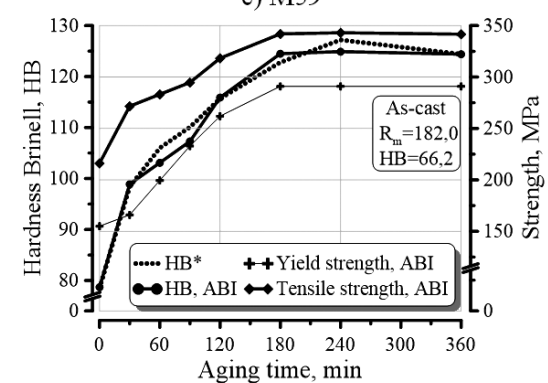

f) MS5

Figure 2: Mechanical properties. ${ }^{*}$ Classical method

Slika 2: Mehanske lastnosti.*Klasična metoda

$$
\begin{gathered}
\psi=\frac{h}{D} \\
a=\sqrt{D h-h^{2}}
\end{gathered}
$$

\section{RESULTS AND DISSCUSION}

\subsection{Mechanical properties}

The values of the $H B$ hardness and $\mathrm{ABI}$ tests are summarized in Figure 2. Figure 4 represents the dependencies of the load-indentation depth, which were recorded in the ABI study. The differences between two curves given in the diagrams (Figure 4) may be connected with the changes in the value of the load $(\mathrm{P})$, leading to a diversity in the indentation depth and differences in the hardness of the materials $(H B){ }^{6}$
Figure 4 shows indentation curves of the alloys in the as-cast state and after the heat treatment (T6).

As the result of the solution treatment, both $H B$ and tensile-strength values are significantly decreased (except for the LP5 alloy). In addition, artificial aging leads to an increase in all the mechanical properties of the alloys.

The change during the heat treatment is the result of several processes, which occur during the heating.

\subsection{Processes which occur during homogenization}

The first process is the eutectic spheroidisation (Figure 3a). A higher solution-treatment temperature leads to a faster eutectic-lamella decomposition into smaller segments and to the spheroidising effect. In ${ }^{8,9}$ is pre-

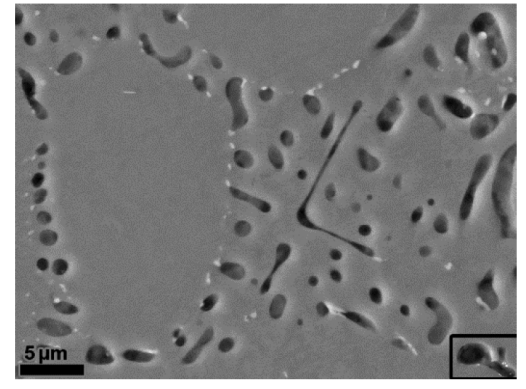

a)

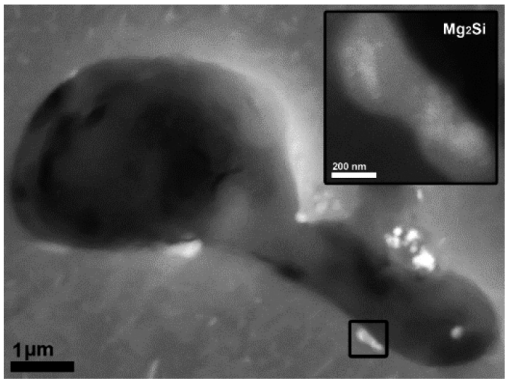

b)

\begin{tabular}{|c|c|}
\hline Element & $\begin{array}{c}\text { Concentration, } \\
\text { in mass } \\
\text { fractions } \\
(w / \%)\end{array}$ \\
\hline $\mathrm{O}$ & 1.6 \\
\hline $\mathrm{Mg}$ & 0.6 \\
\hline $\mathrm{Al}$ & 78.7 \\
\hline $\mathrm{Si}$ & 5.7 \\
\hline $\mathrm{Mn}$ & 7.8 \\
\hline $\mathrm{Fe}$ & 5.6 \\
\hline
\end{tabular}

c)

Figure 3: Processes which occur during homogenization: a) spheroidisation of eutectic lamellas, b) formation of $\alpha$-( $\mathrm{Al}_{15}\left(\mathrm{Mn}_{2} \mathrm{Fe}_{3} \mathrm{Si}_{2}\right)$ dispersoids, c) chemical composition (EDX) of $\mathrm{Al}_{15}(\mathrm{Mn}, \mathrm{Fe})_{3} \mathrm{Si}_{2}$ dispersoids

Slika 3: Procesi med homogenizacijo: a) sferoidizacija lamel evtektika, b) nastajanje disperzioidov $\alpha$-( $\left.\mathrm{Al}_{15}(\mathrm{Mn}, \mathrm{Fe})_{3} \mathrm{Si}{ }_{2}\right)$, c) kemijska sestava (EDX) disperzioidov $\mathrm{Al}_{15}(\mathrm{Mn}, \mathrm{Fe})_{3} \mathrm{Si}_{2}$ 
Table 2: Average compositions of Mn-containing phases in the MS4 and MS5 alloys, measured with EDX Tabela 2: Povprečna sestava faz, ki vsebujejo Mn v zlitinah MS4 in MS5, izmerjenih z EDX

\begin{tabular}{|c|c|c|c|c|c|c|c|c|}
\hline \multirow{2}{*}{ Phase stoichiometry } & \multirow{2}{*}{ Condition } & \multicolumn{6}{|c|}{ Chemical composition, in mass fractions $(w / \%)$} \\
\cline { 3 - 9 } & & $\mathrm{O}$ & $\mathrm{Mg}$ & $\mathrm{Al}$ & $\mathrm{Si}$ & $\mathrm{Mn}$ & $\mathrm{Fe}$ & $\mathrm{Cu}$ \\
\hline$\delta$ - $\mathrm{Al}_{4}(\mathrm{Mn}, \mathrm{Fe}) \mathrm{Si}_{2}$ (acicular-shaped) & $\mathrm{AC}$ & 1.5 & 1.1 & 60.4 & 26.8 & 7.6 & 2.2 & 0.4 \\
\hline$\beta-\mathrm{Al}_{5}(\mathrm{Mn}, \mathrm{Fe}) \mathrm{Si}$ (blocky-shaped, stable) & $\mathrm{ST}$ & 0.5 & 0.2 & 59.2 & 11.9 & 25.1 & 2.4 & 0.7 \\
\hline
\end{tabular}

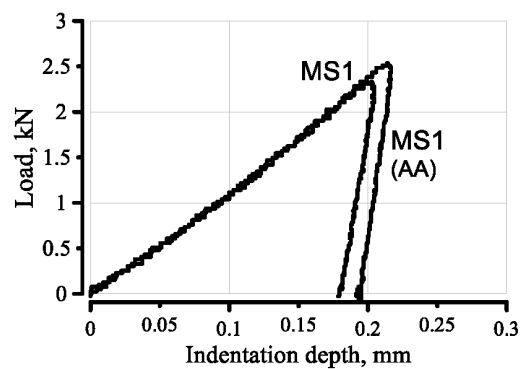

a) MS1

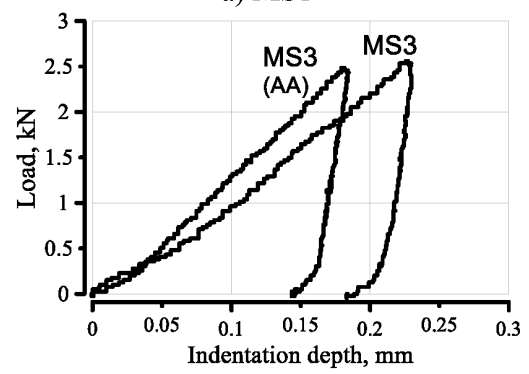

d) MS 3

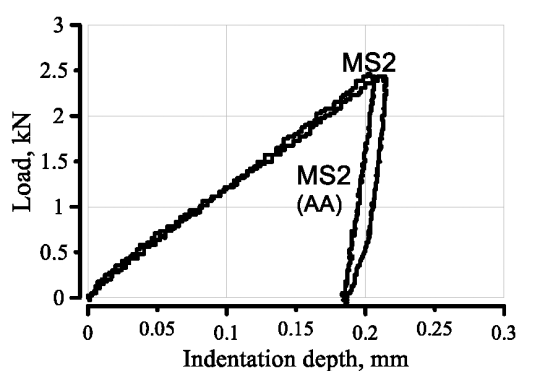

b) MS2

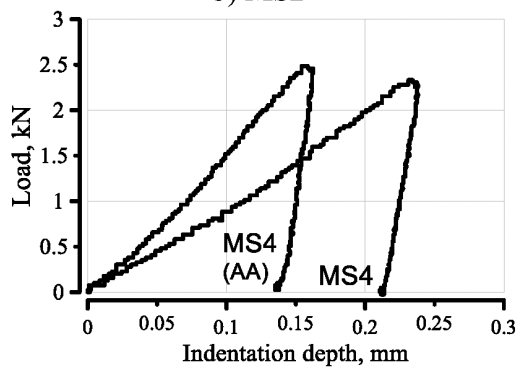

e) MS4

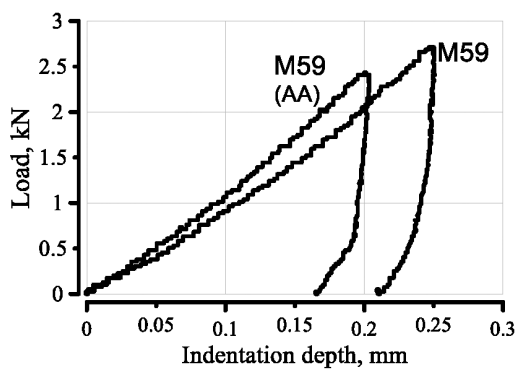

c) M59

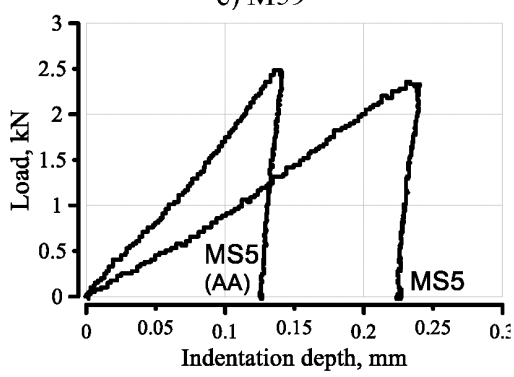

f) MS5

Figure 4: $\mathrm{ABI}$ indentation curves

Slika 4: ABI krivulje pri vtiskovanju

sented a model of the spheroidisation of eutectic lamellas in the alloys of the Al-Mg-Si system. This process leads to a decrease in the hardness of the alloys.

The second process is the dissolution of the primary Mn-containing phases, forming dispersoids, which include $\mathrm{Mn}, \mathrm{Si}$ and Fe (Figure 3). ${ }^{10}$ Particle morphology is shown in Figures $\mathbf{3 b}$ and $\mathbf{5 b}$. These particles can be identified as the $\alpha-\left(\mathrm{Al}_{15}(\mathrm{Mn}, \mathrm{Fe})_{3} \mathrm{Si}_{2}\right)$ phase (Figure 3c). A lack of coherence of phase $\alpha-\left(\mathrm{Al}_{15}(\mathrm{Mn}, \mathrm{Fe})_{3} \mathrm{Si}_{2}\right)$ with $\alpha$-Al probably affects (along with a disintegration of eutectic cells) the decrease in the hardness of the alloys. A dissolution of the $\beta$ ' $-\mathrm{Mg}_{9} \mathrm{Si}_{5}$ particles also occurs during the homogenization.
The last process occurs in alloys MS4 and MS5. This is a transformation of metastable acicular-shaped $\delta$-phases to a more stable state due to diffusion processes. ${ }^{11-13}$ After the solution treatment, the excess silicon from the $\delta$-phase dissolves in the $\alpha$-aluminum solid solution. ${ }^{6}$ As it can be seen from Table 2 and Figure 5f, this process improves the hardness even after the homogenization.

\subsection{Processes which occur during aging}

The remaining processes occur in the solid solution and consist of the formation of nanoscale precipitates via a decomposition of a supersaturated solid solution
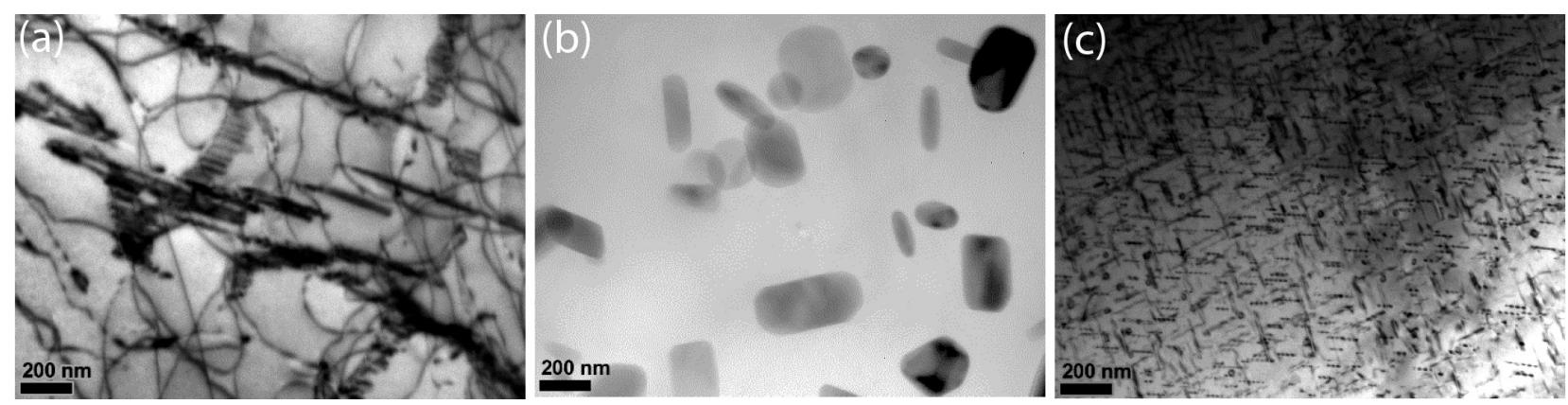

Figure 5: TEM bright-field images of the precipitates in the AlMgSiMn casting alloy: a) as-cast state, b) after homogenization, c) after artificial ageing

Slika 5: TEM-posnetek (svetla polja) izločkov v AlMgSiMn livni zlitini: a) lito stanje, b) po homogenizaciji, c) po umetnem staranju 
(SSSS) during aging (Figure 5). It is established that in the Al-Mg-Si alloys, the decomposition of the supersaturated solid solution takes place during aging and the precipitation sequence is SSSS $\rightarrow$ GP-I $\rightarrow \beta^{\prime \prime} \rightarrow \beta^{\prime} \rightarrow$ $\beta$ - $\mathrm{Mg}_{2} \mathrm{Si}$ where GP-I is the Guiner-Preston zone. ${ }^{12,13}$

Solid-solution grains contain plate-like particles. One of their sides is connected with curved lines, which might be identified as dislocations.

Authors in ${ }^{14,15}$ reported that these particles are formed after natural aging as a result of a heterogeneous nucleation of dislocations. They must be particles of the $\beta$ ' $-\mathrm{Mg}_{9} \mathrm{Si}_{5}$ phase. A direct relationship between the dislocation density and the number of particles it is shown in ${ }^{14,15}$.

As can be seen from the graphs (Figures $\mathbf{4 a}$ and $\mathbf{4 b}$ ), heat treatment does not have a significant effect on the mechanical properties (both the hardness and tensile strength) of the alloys with extra magnesium.

According to the test results (Figure 4), heat treatment of the alloys with extra silicon improves the mechanical properties. With the increasing time of artificial aging (at $175^{\circ} \mathrm{C}$ ), the hardness of the alloys with extra silicon grows. This is due to a sufficient amount of silicon in solid solution needed for forming a larger number of strengthening particles.

\section{CONCLUSIONS}

A higher solution-treatment temperature leads to a faster eutectic-lamella decomposition into smaller segments and to the spheroidising effect, which causes a sharp reduction in the mechanical properties.

Homogenization leads to a dissolution of the primary Mn-containing phases and a formation of dispersoids $\alpha-\left(\mathrm{Al}_{15}(\mathrm{Mn}, \mathrm{Fe})_{3} \mathrm{Si}_{2}\right)$.

Homogenization leads to a transformation of the metastable acicular-shaped $\delta$-phase into a more stable state $(\alpha$ or $\beta$ ) due to diffusion processes.

Artificial aging at $175{ }^{\circ} \mathrm{C}$ leads to a formation of strengthening particles in $\alpha-\mathrm{Al}$, causing an increase in the hardness and tensile strength of the alloys. The difference between the best results for the mechanical properties of the alloys with excess $\mathrm{Mg}$ after the heat treatment and the properties of the as-cast alloys, is not significant.

Comparing the AlSi7Mg and AlMg5Si2Mn casting alloys, the most evident difference is the fact that the highest strength for AlSi7Mg is achieved only after the heat treatment, whereas AlMg5Si2Mn exhibits its highest properties in the as-cast condition.

\section{Acknowledgments}

The authors gratefully thank the Visegrad Fund and DAAD for their support of the research. Trudonoshyn O. and Prach O. would like to thank Mykhalenkov K. for stimulating the investigations and helping us formulate the discussion.
This work was supported by the Ministry of Education, Youth and Sport of the Czech Republic, program NPU1, project No LO1207 and SGS13/186/ OHK2/3T/12 - Research on the influence of surface treatment on the improvement of service life and reliability of exposed water-turbine components.

\section{REFERENCES}

${ }^{1}$ I. N. Fridlyander, V. G. Sister, O. E. Grushko, V. V. Berstenev, L. M. Sheveleva, L. A. Ivanova, Aluminium alloys: promising materials in the automotive industry, Metal Science and Heat Treatment, 44 (2002) 9-10, 365-370, doi:10.1023/A:1021901715578

${ }^{2}$ H. Sternau, H. Koch, A. J. Franke, Magsimal-59, an AlMgMnSi-type squeeze-casting alloy designed for temper F, Aluminium Rheinfelden GmbH, P. O. Box 11 40, D-79601 Rheinfelden, Germany

${ }^{3}$ S. Zajac, B. Bengtsson, C. Jonsson, Influence of cooling after homogenization and reheating to extrusion on extrudability and final properties of AA6063 and AA6082 alloys, Materials Science Forum, 396-402 and 675-680, doi:10.4028/www.scientific.net/MSF.396402.399

${ }^{4}$ H. Lee, J. H. Lee, G. M. Pharr, A numerical approach to spherical indentation techniques for material property evaluation, Journal of the Mechanics and Physics of Solids, 53 (2005), 2037-2069, doi:10.1016/j.jmps.2005.04.007

${ }^{5}$ K. Sharma, P. K. Singh, V. Bhasin, K. K. Vaze, Application of Automated Ball Indentation for Property Measurement of Degraded $\mathrm{Zr} 2.5 \mathrm{Nb}$, Journal of Minerals \& Materials Characterization \& Engineering, 10 (2011) 7, 661-669

${ }^{6}$ M. Puchnin, O. Trudonoshyn, O. Prach, Use of ABI technique to measure mechanical properties in aluminium alloys, Part 1: Effect of chemical composition on the mechanical properties of the alloys, Mater. Tehnol., 50 (2016) 2, 247-252, doi:10.17222/mit.2014.294

${ }^{7}$ P. I. Stoev, V. I. Moschenok, Definition of Mechanical Properties of Metals and Alloys on Hardness, Bulletin of V. N. Karazin Kharkiv National University, 601 (2003) 2(22), 106-112

${ }^{8}$ C. Phongphisutthinan, H. Tezuka, T. Sato, Semi-Solid Microstructure Control of Wrought Al-Mg-Si Based Alloys with Fe and Mn Additions in Deformation-Semi-Solid-Forming Process, Materials Transactions, 52 (2011) 5, 834-841, doi:10.2320/matertrans. L-MZ201119

${ }^{9}$ S. Otarawanna, C. M. Gourlay, H. I. Laukli, A. K. Dahle, Microstructure Formation in AlSi4MgMn and AlMg5Si2Mn High-Pressure Die Castings, Metallurgical and Materials Transactions A, 40A (2009), 1645-1659, doi:10.1007/s11661-009-9841-1

${ }^{10}$ L. Lodgaard, N. Ryum, Precipitation of dispersoids containing Mn and/or $\mathrm{Cr}$ in $\mathrm{Al}-\mathrm{Mg}-\mathrm{Si}$ alloys, Materials Science and Engineering, 283A (2000), 144-152, doi:10.1016/S0921-5093(00)00734-6

${ }^{11}$ O. Trudonoshyn, O. Prach, V. Boyko, K. Mykhalenkov, Selection and Optimization of Heat Treatment Process to Improve the Mechanical Properties of Casting Alloys of the Al-Mg-Si System, Casting Processes, 106 (2014) 4, 12-21

${ }^{12}$ G. A. Edwards, K. Stiller, G. L. Dunlop, M. J. Couper, The Precipitation Sequence in Al-Mg-Si Alloys, Acta Mater., 46 (1998) 11, 3893-3904, doi:10.1016/S1359-6454(98)00059-7

${ }^{13}$ C. Ravi, C. Wolverton, First-principles study of crystal structure and stability of Al-Mg-Si-(Cu) precipitates, Acta Materialia, 52 (2004), 4213-4227, doi: 10.1016/j.actamat.2004.05.037

${ }^{14}$ V. Boyko, T. Link, N. Korzhova, K. Mykhalenkov, Microstructure characterization of AlMg5Si2Mn casting alloy, Materials Science and Technology (MS\&T) 2013, Montreal, Quebec, Canada 2013, 1331-1338

${ }^{15}$ V. Boyko, O. Prach, O. Trudonoshyn, K. Mykhalenkov, Microstructure and Natural Hardening of AlMg5Si2Mn Casting Alloy, Bulletin of NTUU "KPI", (2014), 47-54 